Alfredo D'Attorre. Researcher in Philosophy of Law at Dipartimento di Scienze giuridiche, Università degli Studi di Salerno. He has dealt with the theory of power and legitimacy, doctrines of the State and sovereignty, problems of European integration, legal globalization. He is the author of the monograph Perché gli uomini ubbidiscono. Max Weber e l'analisi della socialità umana (2004) and of several articles published in journals and books, including L'Europa e la metamorfosi della sovranità (2009), Lillusione del "legal standard": diritto e politica dopo la crisi globale (2010), La democrazia tra popolo e populismo (2010), La forma introvabile. L'Europa e la via giuridica all'unificazione (2011).

Contact: dattorre@hotmail.com 


\title{
CLASS STRUGGLE
}

\section{TRANSFIGURATIONS, TENSIONS ${ }^{1}$}

\author{
Alfredo D'Attorre \\ Università degli studi di Salerno
}

\section{Abstract}

The article analyzes the complex and problematic relationship between populist insurgency and the return of the class struggle. The 'populist moment' is interpreted as a counter-movement with respect to the disruptive social results of the thirty-year period of neo-liberal globalization and as an obligatory passage, in the current historical conjuncture, to reactivate the possibility of a distributive conflict in a practicable political space, that of the National State. After the initial onset, however, populism is structurally inadequate, due to its very logic of functioning, to give form to a class struggle anchored in the pluralism of social interests and to resist the risk of reactionary drifts and colonization from above by the dominant economic forces.

\section{Keywords}

Populism, class struggle, deglobalization, law, National State.

\section{Resumen}

Este artículo analiza la compleja y problemática relación entre insurgencia populista y el retorno de la lucha de clases. El "momento populista" es interpretado como un contra movimiento con relación a los resultados sociales disruptivos del periodo de treinta años de globalización neoliberal y como un pasaje obligatorio, en la actual coyuntura histórica, para re activar la posibilidad de un conflicto redistributivo en una 
esfera política práctica, la del Estado nación. Sin embargo, despúes del momento inicial, el populismo se muestra estructuralmente inadecuado para dar forma a una lucha de clases anclada en el pluralismo de los intereses sociales y para resistir el riesgo de cambios reaccionarias y de colonización desde arriba, por parte de las fuerzas económicas dominantes, debido a su propia lógica de funcionamiento.

\section{Palabras clave}

Populismo, lucha de clases, desglobalización, ley, Estado nación. 


\section{After the great crisis: populism as the 'return of the repressed'}

The class struggle is one of the different aspects of the (late) political modernity that the thirty-year period of neo-liberal globalization has tried to file away definitively. Mainstream narrative has not only declared obsolescence, but also the uselessness of the traditional distributive and political conflict between different social classes in the new global world developed since the Eighties of the last century. Just like the National State, political sovereignty and legal order based on legislative law, even class struggle has been described as an element belonging to an era that is coming to an end, that of political modernity opened by the French Revolution and culminating in the 'thirty glorious years' of the second post-war period: all elements that could no longer play a primary or significant role in the post-modern era of deployed globalization.

When the global economic crisis, which began in 2007-8, undermined the consensus of this neo-liberal narrative, which until then was almost unchallenged, it gradually appeared more evident as those that were defined with some reason the 'thirty inglorious years', following the 'thirty glorious years' of the Keynesian compromise between capital and labour, led to the working classes' dispossession of self-awareness ${ }^{2}$, even before the functionality of the instruments of struggle used during the previous century: unions, parties, representative institutions.

The transforming action of neo-liberal hegemony has not only been exercised on economic and political terrain, but has acted on a deeper, anthropological level, colonizing desires, expectations, representations of self, feelings of individuals beyond their class membership ${ }^{3}$. The neo-liberal imagination has thus deconstructed the old social affiliations and loyalties in an even more corrosive way than the productive and technological transformations that have invested the sphere of work. The intrinsically individualistic conformation of this imaginary has deployed a destructuring action with respect to sentiments of collective belonging of a political, trade union and class nature. Consumption, enjoyment, self-affirmation and even self-entrepreneurship have gradually eroded the symbolic and axiological centrality of work. The latter has been increasingly represented as a residue, an encumbrance that has not yet been completely overcome, the persistence of an era that neo-liberal globalization would have definitively concluded with its progress.

2. The indispensability of the element of 'self-consciousness' as a condition for a social class to perform a significant historical-political function was also emphasized by non-Marxist scholars. For example, see Aron, 1964.

3. Among the many works on the subject, see, in particular, Dardot \& Laval, 2009. 
In the neo-liberal imaginary the marginalization of work has been the premise of its depoliticization, that is, of the fact that it ceased to act as the primary foundation of class belonging and of political activity. The territorial uprooting, which also work has suffered, contributed to this process. This uprooting had a double dimension. The first was represented by the fragmentation of production processes and by the phenomena of reduction and delocalization of industrial factory work, the central element of the political-trade union weight and of the self-consciousness of the working class in the previous phase. The second was determined by the emptying of the national political community as a primary place for the organization and class struggle ${ }^{4}$. Even the political and trade union representatives of the working classes have introjected the narration of the decline of the national State as an arena and arbiter of distributive conflict, based on the intangibility of the neo-liberal dogma of the absolute freedom of movement of capital, goods and services (to which workforce is added in the European Union of the 'four freedoms of movement').

In this dimension of deployed globality, relieved of the constraints and regulatory barriers of national legal systems and placed as far as possible away from elements of interference and regulation of democratic political powers, finance capital affirms its expansive und unchallenged power, changing radically to its own advantage the balance of power with work ${ }^{5}$. The famous phrase of one of the greatest exponents of the global financial establishment, Warren Buffet, according to which the class struggle had not ceased at all, but was simply swept up by the capitalists, well describes the absence of political, juridical, cultural, ideological limits, that marked the predominance of capital over labour during neo-liberal globalization. It is now a recognized fact that this also depended on the loss, after the collapse of real socialism, of any geopolitical counterweight to Western capitalism.

The great financial crisis can be interpreted as the heterogenesis of the intents of this immeasurable victory -without more internal and external constraints- of financial capitalism on its class opponent: labour. The drastic reduction of the wages share with respect to the total wealth, the total disconnection between the growth of labour productivity and stagnation, or even reduction of wages, the exponential growth of private debt to support consumption, and the deterioration of public welfare are revealed, at at the same time, as the effect of this overwhelming victory of capital and the cause of

4. For a specific analysis of the effects of the emptying of the political-State regulation on the functioning of the capitalist system, see, among others, Gallino, 2011; Leon, 2014.

5. Among the most recent works, for a critical analysis of the effects of financial globalization on the legal field, see Ferrarese, 2017. On the more strictly political-economic implications see Rodrik, 2017. 
the loss of balance of the major capitalist economies ${ }^{6}$. It should be noted that these economic transformations, so profound and 'disorderly' for to the social balance achieved in the decades of the 'Keynesian compromise', have not found a restraining force in law, nor in the common law derivation, nor in that of civil law. The national legal systems, weakened in their political-territorial legitimacy and attracted by the sirens of a legal cosmopolitanism and a global constitutionalism trusting in the emancipatory and progressive potentialities of the wave of globalization, were permeated by the devices of neo-liberal economic governance, genetically allergic to the recognition of a plurality of objectively conflicting interests.

The colonization of legal and representative systems by neo-liberal orthodoxy, which denies the legitimacy of the distributive conflict between divergent interests, determines a growing inability of the liberal-democratic order to recognize and channel into its mechanisms an increasing share of social demands. The populist insurgency, which in various forms crosses the West since the outbreak of the economic crisis, is above all the consequence of this situation. The occlusion of the legal, political and representative channels that allowed the distributive conflict between different social interests to develop within the liberal-democratic systems of the nation-States makes the class struggle re-emerge with the strength and the unruliness of a sort of 'return of the repressed. Populism thus reconfigures the class struggle as an insurgency from the bottom stripped of the previous representative forms, strongly polarized and tendentially refractory to any form of political mediation in the traditional sense.

\section{The populist counter-movement and its contradictions}

At this point, we bump into the problem of the complex, unstable and contradictory relationship between populist insurgency and the return of the class struggle, which takes place in a socio-psychological context still dominated by the neo-liberal imagination, in which class consciousness is not reconstituted with its traditional link to the dimension of labour. This change in social psychology has no less impact than the dispersion and pulverization of forms and types of work in an economy increasingly dominated by services and the digital world. The processes of political subjectification become even more irreducible to a sociological nomenclature of the classes, if they were

6. On these phenomena and on their internal connection, see, in particular, Streeck, 2017. 
mechanically in the previous phase. The theory of Ernesto Laclau and Chantall Mouffe captures here a crucial point in the transformation of contemporary politics and in the difficulties of the less aware forms of Marxist analysis of social conflict ${ }^{7}$. In a condition characterised by an increased cultural pluralism, a weakening of feelings of belonging to territorial and social communities and a tendency towards increasingly driven processes of individualization, the 'people', i.e. the subject of collective political action, must be constructed artificially. Its capacity for action, its recognition in unifying battles and in a community of destiny are not given in the objectivity of social reality, but must be produced by a political design capable of linking together only different and prima facie potentially even among them conflicting instances.

The consequence of this artificial construction of the collective political subject and this is an element that perhaps does not receive all the necessary consideration by Laclau and Mouffe- is that its identity bond inevitably becomes cultural rather than socio-economic. A confirmation of this shift of political dynamics in the era of neo-liberal hegemony also comes from the fact that, in the decades preceding the global economic crisis, the traditional right/left axis was re-articulated to a largely prevalent extent on the identity-cultural dimension, largely losing the capability to describe and represent the traditional distributive conflict between capital and labour. The conservative/progressive dichotomy replaces the liberal/socialist dichotomy, substantially disabled by the affirmation of the dictatorship of the notorious 'TINA' (There Is No Alternative) of Thatcher's ancestry in the field of economic policies. The outcome of this re-semantization of the right-left dialectic is that the working classes are deprived of political representation directly linked to their material interests. In European and Western political left, prevails what Nancy Fraser calls a "progressiv Neo-liberalism» (Brenner \& Fraser, 2017), charachterized by the conjunction of a very open and advanced individualism in the field of civil and freedom rights with a substantially liberalist and anti Keynesian approach in the economic-social field.

The 'populist moment' is above all the effect of a historical counter-movement against the long hegemonic phase of this neo-liberal individualism, which marked the decades before the global crisis. The laceration of every protective fabric in cultural and economic terms produced by the ascending phase of globalization leads to a sort of backlash, a violent compensatory reaction, which translates into a new need for belonging, community, identity, social bond. This happens without the mediations and

7. For the more detailed exposition of this theory and its philosophical assumptions, see Laclau, 2005. 
intermediate structures on which the liberal-democratic order is founded. On the contrary this process takes place in a reactive and immediate way, searching for areas of homogeneity and mutual recognition as close and as narrow as possible. The new forms of digital communication and social networks, rather than diluting their memberships in a new global horizontality capable of dissolving every cultural boundary (as expected from a certain rhetoric of globalization), lead and emphasize this search for 'identity niches', built in a strongly agonistic way with respect to the 'strangers'.

Therefore the populist moment brings the risk of a pathological drift of the post-crisis shift of the Zeitgeist of the West towards a more communal dimension, triggered by the sense of anomie and uprooting produced by the full unfolding of liberal individualism and the disruptive effects of contemporary financial capitalism. Populism triggers dynamics that can push the pendulum towards an opposite and specular polarity with respect to the individualistic atomism of the previous phase: from the refusal of the concept of society itself («society does not exist, individuals exist», according to a liberal thought line, which from the Austrian School of Economics comes up to Margaret Thatcher) to the risk of a return to a community intended for organic totality, far beyond the «anti-essentialist» artificiality of the «chain of equivalences» described by Laclau and Mouffe ${ }^{8}$. This is also revealed by the return of the national dimension as the primary field of political conflict. This momentum, patently anthitetical to the de-territorialization of politics and law, holds the potential for a revitalization of democratic participation and popular sovereignty, but at the same time it brings the risk of a regressive and exclusive re-configuration of the national community, in which populism assumes a xenophobic fold and the social articulation of conflict is replaced by an appeal to the homogeneity and innocence of the original community, threatened by an external enemy whose otherness is depicted as irreducible.

\section{The structural heterogeneity between populist insurgency and class struggle}

The terrain of political conflict in the current phase of de-globalization, however, is the one designed by the populist insurgency, which in this historical bend is

8. The outcome of this populist dynamic is truly paradoxical, if we consider that, albeit in a profoundly different theoretical sense from the Thatcherian one, the thesis that «society does not exist» is also the basis of the "post-Marxist» and «anti-essentialist» theoretical turn that Laclau and Mouffe accomplished in the mid-Eighties. See Laclau \& Mouffe, 2001, p. 114. 
redesigning the language and political grammar of all the forces in the field, subjecting to a strong tension the usual functioning dynamics of the liberal-democratic systems. As a result, in the current historical conjuncture the resumption of the class struggle can only pass initially through the narrow path of populism. However, this should not lead to the theoretical error of identifying populist insurgency and class struggle. Populism is the obligatory step to reactivate the distributive conflict, but it cannot be structurally thought of as the functional substitute for the construction of 'historical-social blocks'. This element is indispensable for transforming the populist insurgency into a class struggle endowed with coherence, continuity and strategic vision ${ }^{9}$. The reason lies in the fact that the populist mechanism of consensus building, after the initial onset, appears inadequate to the direction of a strategic action, anchored to concrete and determined social interests, capable of an actual transformation of forces and power relations within a political and social order.

According to the conception of Laclau and Mouffe, «anti-essentialism» becomes a sort of essence of populism and its differential characteristics with respect to other forms of political action. However, the artificial and discursive character of the construction of the people is exposed to the risk of eliminating the economic-social roots of collective belonging and political conflict. The 'people', understood as a constructivist outcome of a «chain of equivalences» drawn up on the basis of a political design, is exposed to various forms of simplification and reductionism. In this sense the «anti-essentialism» is exposed to many traps, if we imagine the populist device as the way to reactivate a distributive conflict in which the interests of the subaltern classes return to have an effective weight. The first and most evident of this traps is a reactoinary reading of the populist discourse, based on the claim of an original and uncontaminated homogeneity of the people and on the removal of the conflictual pluralism of the economic-social interests that cross it.

On the other hand, we can say - to misquote the well-known joke attributed to Gioacchino Rossini about the work of a young composer- that something true and something new lies in the "anti-essentialist» twist of the populist theory, but what is true is not new and what is new is not true ${ }^{10}$. The intrinsically political and 'hegemonic' character of the process of building a party and its people is widely explored in the Marxism of Antonio Gramsci ${ }^{11}$, as demonstrated on the historical-political ground, to take the

9. For an analytical perspective of populism that does not exclude this possibility, see Formenti, 2016.

10. For an earlier and more problematic position of the same Laclau with respect to this «anti-essentialist» twist, even if already not crushed on a mechanical class reductionism, see Laclau, 1977.

11. For an analysis of the question of egemony in the Gramscian Quaderni with respect to the function of law, see Prete- 
example of Italy, by the awareness of the leading group of the post-war PCI, starting from Togliatti, that the party-subject certainly could not be reduced to a mere «class nomenclature». The wisest forms of historical materialism have always had the non-mechanical relationship between social position and political representation in mind. And yet, without the persistence of a social anchorage, without a nucleus of 'essentialism', the construction of a 'chain of equivalences' between different instances of struggle and claim is more exposed to the risk of forms of 'ethnicist' reductionism, which characterize reactionary populism, or, on the other hand, colonization and hetero-direction by dominant economic interests.

This risk is even accentuated in a situation like the current one, marked by a more communitarian Zeitgeist compared to the ascending phase of neo-liberal globalization. It has been said that, from this point of view, the populist insurgency marks a sort of 'historical-spiritual' counter-movement, particularly evident with respect to the outcomes of the conjunction between the individualistic and libertarian roots of the youth protest movements of the sixties and seventies of the last century and the «spirit of the new capitalism», according to the category of Weberian ancestryb (reworked by Boltanski \& Chiapello, 1999). From this point of view, it is necessary to recognize the inevitability of the populist moment as a necessary step to question the consensus, unchallenged in the West up to the global economic crisis, of the neo-liberal order and to reopen a space of conflict practicable by social and ideological interests distinct from those of financial capital. At the same time, and back to the basic point, in the medium-long term populism is inadequate to give a stable political form to the dynamics of the class struggle. The reduction of political conflict to binary schemes such as people vs. elite or low vs. high can not structure a lasting and democratic dialectic between divergent social economic interests, among which it is necessary to build spaces of conflict and at the same time of mutual recognition and temporary mediation.

\section{Populist disintermediation and the risk of colonization from above}

This crucial aspect is closely linked to the device of disintermediation between political leadership and the people, on which the populist discourse is based. The political and social intermediate bodies, under pressure forthe individualizing atomism

rossi, 2018. On the role of law in the Gramscian articulation of the nexus 'structure-superstructure' see also, among recent works, Gazzolo, 2018. 
of neo-liberal order, are emptied of their residual resources of mobilization and circumvented by the populist dynamic, in itself incompatible with the recognition of their function. The deactivation of intermediate bodies is one of the elements that helps to blow up the coexistence, the intersection and the balance between social legitimacy and moral legitimization of political conflict in populist discourse. This articulation is broken because the populist construction of the 'we' leads to a radical delegitimization of reasons and interests of excluded and averse side of society. The impending risk is a radical polarization of the friend-enemy clash on a field of moral and 'existential' delegitimization of the Other, rather than on the field of the recognition of an interests divergence to be faced and composed. The populist discourse is exposed to the slipping into a sort of 'moralistic' other TINA, opposite and specular to the dictatorship of the neo-liberal imaginary and the politically correct, which had marked the previous phase.

On one hand this moral radicalization of conflict undermines the capability of populism to transform social and economic relations; on the other, it increases the risk of colonization from the top of the populist insurgency. The articulation of the "chain of equivalences» can be dominated by instances, strategically fed by powerful financial and media conditioning centers, which redefine the hierarchy of the objectives of the conflict on an axis that does not exactly coincide with the primary interests of the lower classes, which also constitute the basis of primary accumulation and the indispensable initial propellant of the populist dynamics ${ }^{12}$.

The risk of a colonization from above of this people vs elite dynamic is exemplified by the way in which its charge of contestation has often been diverted from its natural target, the global economic-financial class with its substantial class interests, and converted into a generic as well as strong 'anti-political' sentiment, based on the indistinct rejection of the political ruling classes and on the indignation for the functioning costs of representative democracy. The 'anti-political' torsion of populism has identified the political parties and sometimes even the unions as the target of a destructive criticism, aimed not at stimulating a renewal of their function and organization, but at denying their usefulness in the age of disintermediate democracy. The problem is that this denial of the role of intermediate bodies is singularly convergent with one of the instances carried out with greater determination by the last decades neo-liberal offensive.

12. For the thesis of the non-extraneousness of the populist moment to the fundamental devices of neo-liberal hegemony, see, in particular, Bazzicalupo, 2014. 
In this case the colonization from the top of the populist insurgency produces a quite paradoxical effect: to reinforce a project of social and political atomization, in accordance with one of the fundamental aims of neo-liberal globalization, the main opponent against whom the populist insurgency was born. The big capital doesn't need political parties or public financing to enforce its demands on public institutions. On the contrary, it does not miss the opportunity to re-direct the populist wave against another elite, the political one. In this way, as long as this 'colonizing populism from above' strategy work, capitalist classes obtain two significant achievements: to keep their material class interests safe, away from the battlefront, and make the political class weaker, i.e. poorer in both material resources and legitimacy, and therefore more in need of their economic and media support, with everything that follows.

This destructuring of the intermediate bodies, which populism often leads to, takes us to the fact that in many contexts, in the current situation, the populist way is the last and only one to reactivate a sort of social conflict not restricted to single topics or protests. But still, it is patent that it is inadequate to restore subjectivity and political autonomy for the working class in a more stable and effective configuration. In this sense, the «anti-essentialism» inherent in the construction of populist discourse shows its main lack: it can not identify a core of shared interests and convictions which is essential for establishing a political feeling of belonging to a collective battle in lasting and resistant terms. The people, the fruit of the purely discursive construction of a «chain of equivalences», seems to be a much more unstable, colonizable and fragile political subject than the class. Without the reactivation of the class as political subjectivity, the world of work is thus deprived of an effective instrument to counteract its shattering, marginalization and subordination in the neo-liberal order, of which the populist insurgency fails to question the fundamental structures of economic domination.

\section{De-globalization, class struggle and national State}

Nonetheless in a first phase the populist reaction to the neo-liberal order manages to produce the re-politicization of the national public space. The populist moment reconstructs a potentially productive nexus between class struggle and State-institution, re-delimiting a practicable area of conflict and also giving a political dimension to the process of de-globalization that started economically after the great crisis in 2008. 
At this point we come across a crucial theme that has passed through theoretical reflection and political discussion in the Marxist sphere: the relationship between class struggle and the function of the national State. It is a strongly debated issue, from which profoundly different interpretations ${ }^{13}$ and political translations of Marxism have been derived. Without entering into a Marxist tradition's internal interpretative controversy, if we look at the history of the twentieth century, it is nevertheless hard to deny that the control or at least a certain degree of State power conditioning was the condition which allowed the distributive conflict to develop with the historically more favorable outcome for the working classes.

Since the Eighties, the neo-liberal narrative of the end of the regulatory function of the State in the globalized world is accepted by growing sectors of political and trade union forces representing the working classes. It has also happened that a part of the left of Marxist inspiration has been convinced that globalization created new possibilities for conflict and emancipation and that it was opening up the field to a more fruitful and promising global class struggle, completely unrelated to national belonging and from the residual regulatory abilities of State sovereignties. It was obviously a pious illusion, against which during the thirty years of neo-liberal globalization the real history of the change in the balance of power between classes has pronounced its "harsh replies», in the words of Norberto Bobbio about the collapse of real socialism. The States have not disappeared and a globality rich in emancipatory potentialities has not been deployed for the new «multitudes» that should have taken the place of the national working classes. Instead, the political direction of the States has been just colonized, with increasingly weak resistance, by the interests of transnational financial capital, unchained from 'sovereign' control and capable, thanks to, among other things, its freedom of movement, of conditioning national political powers with effectiveness and pervasiveness far greater than the previous phase. The idea that workers and migrants could exploit the freedom of movement and the permeability of borders in an equally or more advantageous way than financial capital served to write books that, in the triumphant phase of neo-liberal globalization, experienced a certain editorial success ${ }^{14}$ (not inexplicable given the cultural directives of the time...), but showed a very problematic adherence, to say the

\footnotetext{
13. For a critique of the Marxist doctrine of the State, which would have acted historically as a weakening factor in the struggle of the working class against capital, see recently Pivetti, 2017. Instead, for a strong emphasis on the centrality of the national issue in the Marxist-Leninist tradition and the political impotence of the post-' 68 Western maxism strands, which have lost this awareness, see Losurdo, 2015, pp. 146 ss. From a Marxist perspective, for an analysis of the evolutionary phases of modern capitalism in relation to the transformation of the forms of State political power and the impact of the class struggle, see, above all, Arrighi, 2014.

14. The paradigmatic case is represented by Hardt \& Negri, 2000.
} 
least, to the empirical reality and to the concrete evolution of the power relations between classes.

Populism offers the opportunity to re-politicize a space, the national one, potentially viable for the reopening of the distributive conflict. But it also opens, as has been said, the possibility of a declination of this space in terms of compact block, of organic totality, with opposite and specular results to those of the atomization produced by neo-liberal hegemony. Both paradigms are substantially incompatible with the structuring of a distributive conflict socially anchored and recognized on the political-institutional level. The device of neo-liberal atomization inhibits the class struggle because it prevents the consolidation of feelings of collective belonging and communities of interests; the model of organic totality because it does not recognize and legitimize the irreducible and conflicting pluralism of the interests that run through society, outside the binary framework founded on the contrast between a restricted elite and the vast majority, the 'healthy' part of the social body, represented as a bearer of common interests.

After the social and political effects of the great crisis, the reactivation of a regulated and vital class struggle can now be recognized as a fundamental requirement for western democracies and for their possible regeneration. The resumption of the class struggle is thus faced with the need to use the populist moment without being absorbed and neutralized by its logic: which means, for example, using the gap opened by populism to reactivate the possible transformative function of national popular sovereignty in a progressive and emancipatory sense, avoiding the risk of being sucked into the whirlpools of 'ethnicist' and reactionary nationalism. Class struggle implies a not unidimensional or organic concept of political community. It's rather intrinsically pluralist, and therefore open to internal conflict and integration through successive steps and necessarily unstable balancing.

\section{The class struggle and the re-politicization of law}

The class struggle shows elements of tension even with a certain declination of the concept of 'common good' or with an idea of law founded on conformity to 'moral principles of justice. A constitutionalism that sets the institutional framework and the perimeter of shared ethical-political convictions, within which social and democratic dialectics can develop, is a support to a regulated and productive distributive conflict. An «irenical» (Luciani, 2006) or global constitutionalism, which cuts the political root 
of law and assigns its legitimacy to a jurisdictional 'ethicalization' (which is increasingly assigned to the prevalence of transnational courts that are hardly permeable to the demands of the economically weaker and less dynamic part of society), constitutes instead an obstacle and a potential factor of ideological delegitimization for a class struggle aimed at substantially modifying economic power relations and their political-juridical projection $^{15}$.

If we think about, for example, a conception of law such as that of Ronald Dworkin, which has exercised a considerable influence on a large part of contemporary neo-constitutionalism, it is difficult to imagine how a conception of the class struggle as a dynamic process, that aims to continually shift the juridical equilibrium in society, can coexist with an idea of law founded on the thesis of «one-right answer» (Dworkin, 1985, pp. 119 ss.), which the judge would be responsible for identifying from time to time, on the basis of a unitary and coherent corpus of overarching principles with respect to the legislative rules. At the same time, the class struggle is challengend in its crucial function for the democratic dialectic and process by conceptions which tend to accentuate the purely deliberative and discursive side of the latter, essentially trying to deny the irreducibly 'agonistic' root of politics and, in particular, of democratic politics ${ }^{16}$. The idea that organizing public discourse in the most rational, transparent and informed way can overcome disagreement and conflict carries with it the risk of denying the conflicting existence of a plurality of economic interests and the consequent implicit delegitimization of those among them that are more divergent from the mainstream consensus which dominates the debate in the public sphere.

From this point of view, the populist moment offers the trigger for a re-politicization of the discourse on liberal democracy and law with respect to the prevailing political-juridical conceptions during the thirty years of neo-liberal globalization. The populist insurgency has the merit of unmasking the pretense of neutralization promoted by a global right that is undocked by political mediation and by amministrative and territorial specificity. But populism, after the initial onset, fails to structure the economic-social dimension of the conflict and to guarantee the political-juridical legitimacy of the complex plurality of interests in the field, not reducible to the dichotomy low vs. high. The anti-establishment discursive rhetoric, which translates into the

15. On the difference between the historicistic conception of class struggle and a static theory of rights on liberal basis, see recently Galli, 2018, pp. 126 ss.

16. See on this point, also for an explicit theoretical controversy with Rawls and Habermas, Mouffe, 2005, 2018. For a more articulated reconstruction of the relationship between conflict, legitimacy and hegemony in late political modernity, see Preterossi, 2015, in a critical dialogue with the theses of Laclau and Mouffe. 
image of $99 \%$ of the society fighting against $1 \%$, after the healthy initial shock to the ideological dictatorship of the neo-liberal order, risks slipping into a new organicism of the 'common good'. Low vs. high reductionism and the difficulty of recognizing and articulating the pluralism of internal interests even to $99 \%$ of society open the way to the temptation to morally or 'organicistically' legitimate (the natural unity of the 'healthy' part of society) a new political-juridical order, with all the possible reactionary or regressive risks deriving from it. And with the paradox that the weakening of the economic-social root in the populist construction of the people - the real poisoned fruit of the "anti-essentialism» - leads to morally legitimize a new equilibrium that, if analyzed in its concrete contents and in the real power relations it preserves, it does not appear so distant and revolutionary with respect to the neo-liberal order against which populism had arisen.

\section{References}

Aron, R. (1964). La Lutte des classes. Paris: Gallimard.

Arrighi, G. (2014). Il lungo XX secolo. Denaro, potere e le origini del nostro tempo (1996). Milano: il Saggiatore.

Bazzicalupo, L. (2014). Come in uno specchio. Populismo e governamentalità neoliberale. Cambio. Rivista sulle trasformazioni sociali, 4(8), 25-34.

Boltanski, L. \& Chiapello, E. (1999). Le nouvel esprit du capitalisme. Paris: Gallimard.

Brenner, J. \& Fraser, N. (2017). What is Progressive Neoliberalism?: A Debate. Dissent, 64(2), 130 ss.

Dardot, P. \& Laval, C. (2009). La nouvelle raison du monde. Paris: La Découverte.

Dworkin, R. (1985). A Matter of Principle. Cambridge: Harward University Press.

Ferrarese, M.R. (2017). Promesse mancate. Dove ci ha portato il capitalismo finanziario. Bologna: Il Mulino.

Formenti, C. (2016). La variante populista. Lotta di classe nel neoliberismo. Roma: DeriveApprodi.

Galli, C. (2018), Marx eretico. Bologna: Il Mulino.

Gallino, L. (2011). Finanzcapitalismo. La civiltà del denaro in crisi. Torino: Einaudi.

Gazzolo, T. (2018). Antonio Gramsci e la teoria del diritto. Materiali per una storia della cultura giuridica, 48(2), 327-350.

Hardt, M. \& Negri, A. (2000). Empire. Cambridge: Cambridge University Press. 
Laclau, E. (1977). Politics and Ideology in Marxist Theory. London: New Left Books.

Laclau, E. (2005). La razón populista. Buenos Aires: Fondo de cultura Económica.

Laclau, E. \& Mouffe, C. (2001). Hegemony and Socialist Strategy. London-New York: Verso.

Leon, P. (2014). Il capitalismo e lo Stato. Crisi e trasformazione delle strutture economiche. Roma: Castelvecchi.

Losurdo, D. (2015). La lotta di classe. Una storia politica e filosofica. Roma-Bari: Laterza.

Luciani, M. (2006). Costituzionalismo irenico e costituzionalismo polemico. Giurisprudenza costituzionale, 2,1643-1669.

Mouffe, C. (2005). On the Political. London: Routledge.

Mouffe, C. (2018). For a Left Populism. New York: Verso.

Pivetti, M. (2017). Sulla dottrina marxista dello Stato. Una nota nel centenario della rivoluzione d'ottobre. Costituzionalismo.it, 3 .

[http://costituzionalismo.it/download/Costituzionalismo_201703_649.pdf]

Preterossi, G. (2015). Ciò che resta della democrazia. Roma-Bari: Laterza.

Preterossi, G. (2018). La pensée gramscienne du droit dans les Cahiers de prison. Droit \& Philosophie, 10: Marx e le Droit.

[http://www.droitphilosophie.com/article/lecture/la-pensee-gramscienne-du-droitdans-les-cahiers-de-prison-239.com]

Rodrik, D. (2017). Straight Talk on Trade: Ideas for a Sane World Economy. Princeton: Princeton University Press.

Streeck, W. (2017), Buying Time: The Delayed Crisis of Democratic Capitalism. New York: Verso. 
